\title{
TRANSFORMACJA CZŁOWIEKA W JEDNOSTKĘ ORGANIZACYJNĄ W PRAWIE HANDLOWYM - DOPUSZCZALNOŚĆ, CHARAKTER PRAWNY, PRZESŁANKI I SKUTKI PRAWNE
}

\author{
TRANSFORMATION OF A HUMAN ORGANIZATION UNIT IN COMMERCIAL
} LAW - ACCEPTANCE, LEGAL NATURE, MESSAGES AND LEGAL EFFECTS

\begin{abstract}
Streszczenie: Opracowanie dotyczy problematyki dopuszczalności, charakteru prawnego, przesłanek i skutków prawnych transformacji człowieka w znaczeniu prawnym, tj. osoby fizycznej w jednostkę organizacyjną na gruncie prawa handlowego. Przedstawiono w nim zagadnienie dopuszczalności i charakteru prawnego transformacji osoby fizycznej w jednostkę organizacyjną, przesłanki transformacji (przekształcenia) osoby fizycznej prowadzącej działalność gospodarczą - tzw. przedsiębiorcy jednoosobowego w jednoosobową spółkę kapitałową, przesłanki transformacji (przekształcenia) osób fizycznych będących wspólnikami spółki cywilnej w spółkę handlową, a także najważniejsze konsekwencje prawne tych transformacji człowieka (osoby fizycznej) w jednostkę organizacyjną. W podsumowaniu opracowania umieszczono sygnalizacyjnie najważniejsze wnioski wynikające $z$ dokonanej w nim analizy.
\end{abstract}

Słowa kluczowe: transformacja, przekształcenie, człowiek (osoba fizyczna), jednostka organizacyjna, prawo handlowe

Received: 08.2018
Abstract. The study deals with the issues of admissibility, legal character, premises and legal consequences of human transformation in a legal sense, i.e. a natural person in an organizational unit under commercial law. It presents the issues of admissibility and legal character of the transformation of a natural person into an organizational unit, the premises for the transformation (modification, transition) of a natural person running a business - so-called a sole trader to a soleshareholder company, reasons for the transformation (modification, transition) of natural persons who are partners in a civil partnership into a commercial partnership or company, as well as the most important legal consequences of these transformations of a person (a natural person) into an organizational unit. The summary of the study includes signaling the most important conclusions resulting from the analysis.

Key words: transformation, modification (transition), person (natural person), organizational unit, commercial law.

Accepted: 09.2018

* Dr hab., Uniwersytet Marii Curie-Skłodowskiej w Lublinie 


\section{Wstęp}

Na początku tej wypowiedzi wypada dokonać dosyć oczywistego, prostego, być może dla niektórych wręcz banalnego spostrzeżenia o wymiarze generalnym. We współczesnym świecie, co dotyczy także Rzeczypospolitej Polskiej, na podstawie analizy źródeł wiedzy o postępie cywilizacyjnym, w tym technicznym, dostępnych dla przeciętnego człowieka, co odnosi się również m.in. do autora tego opracowania, nie ma fizycznej możliwości transformacji - w tym połączenia, podziału czy przekształcenia - człowieka w ogólności, np. w inną istotę żyjącą (innego człowieka czy zwierzę). Tym bardziej, wziąwszy pod uwagę aktualną wiedzę w tym obszarze, trudno wyobrazić sobie możliwość transformacji człowieka w rodzaj fikcyjnej z perspektywy fizycznej egzystencji we współczesnym świecie, konstrukcji prawnej, określanej jako jednostka organizacyjna [Longchamps de Berier, 1922, 108, Zoll, 1946, 104, Wolter, 1986, 191, Radwański, 2003, 191; Frąckowiak (w:) Ogiegło (red.), Popiołek (red.), Szpunar (red.), 2005, 901 i n., Frąckowiak, Safjan (red.), 2007, 1020-1026], w tym osoba prawna albo jednostka organizacyjna niemająca osobowości prawnej, której ustawa przyznaje zdolność prawną [Sokołowski (w:) Kidyba (red.), 2012, 19]. Człowiek jako istota żyjąca, żywy organizm nie podlega transformacji. Jego fizyczne transformacje, według aktualnego stanu wiedzy nie mogą prowadzić do powstania jednostki organizacyjnej. Koncepcje dopuszczające wbrew powyższemu taką możliwość obecnie albo przewidujące potrzebę takiej transformacji w niedalekiej przyszłości, wypada pozostawić raczej w obszarze tzw. fikcji naukowej (science-fiction), albo wręcz tzw. rzeczywistości wirtualnej czy też bajkowej, będącej przeciwieństwem rzeczywistości „faktycznej” oraz rzeczywistości prawnej (odnoszącej się do aktualnego stanu prawnego).

Z tej perspektywy celem niniejszego opracowania jest dokonanie na podstawie analizy powszechnie obowiązujących przepisów prawa, a także wypowiedzi zawartych zwłaszcza w literaturze przedmiotu, ustalenia dopuszczalności oraz zakresu transformacji w znaczeniu prawnym (transformacji prawnej) człowieka - osoby fizycznej w jednostkę organizacyjną w obszarze jednej z wyspecjalizowanych dziedzin (gałęzi) prawa prywatnego, tj. prawa handlowego. W związku z tak zakreślonym celem, za niezbędne uznano poddanie $w$ tym opracowaniu analizie, poza kwestią prawnej dopuszczalno- 
ści, także zagadnienia charakteru prawnego, przesłanek i konsekwencji prawnych przewidzianych dla człowieka transformacji w jednostkę organizacyjną. W opracowaniu posłużono się przede wszystkim metodą formalnodogmatyczną.

\section{Dopuszczalność i charakter prawny transformacji w znaczeniu prawnym czło- wieka - osoby fizycznej}

Do podstawowych rodzajów transformacji sensu stricto podmiotów prawa (w tym osób fizycznych, osób prawnych, a także jednostek organizacyjnych nie mających osobowości prawnej, którym ustawa przyznaje zdolność prawną) należy zaliczyć łączenie, podział i przekształcenie. Są one przewidziane w przepisach odnoszących się ściśle do określonych podmiotów prawa, np. w przepisach Kodeksu spółek handlowych [Ustawa z dnia 15 września 2000 r., tekst jedn.: Dz.U. z 2017 r., poz. 1577 ze zm., dalej: k.s.h.], m.in. w odniesieniu do tychże spółek, wspólników spółki cywilnej, a także tzw. przedsiębiorcy jednoosobowego czy też w przepisach ustawy - Prawo spółdzielcze [Ustawa z dnia 16 września 1982 r., tekst jedn.: Dz. U. z 2017 r., poz. 1560, dalej: pr. sp.], m.in. w odniesieniu do tzw. spółdzielni działających na zasadach ogólnych, czy spółdzielni pracy. Trzeba mieć przy tym na uwadze, że przekształcenie jako rodzaj transformacji spółdzielni jest możliwe jedynie w odniesieniu do spółdzielni pracy i dotyczy przekształcenia spółdzielni pracy w spółkę handlową [szerzej w tym zakresie zwłaszcza Szumański, 2011, nr 1, 16 i n., Witosz, Herbet (red.), Zakrzewski (red.), 2014, 149 i n., Kozieł, Herbet (red.), Zakrzewski (red.), 2014, 54-64]. Na gruncie poszczególnych przepisów prawa odnoszących się do określonych podmiotów prawa, każdy z tych rodzajów transformacji ma swoje prawne podstawy, konstrukcję i konsekwencje, w określonych aspektach zbliżone jednak nie tożsame. Za modelowe w stosunku do pozostałych rodzajów transformacji można uznać uregulowania prawnych podstaw, konstrukcji i konsekwencji transformacji spółek handlowych, a także - w określonym, mniejszym stopniu oparte na nich unormowania prawne tego obszaru odnoszące się do spółdzielni. Pozostałe prawne transformacje innych niż spółki handlowe i spółdzielnie podmiotów prawa należy uznać za oparte konstrukcyjnie przede wszystkim oraz w obszernym zakresie na transformacjach spółek handlo- 
wych (natomiast w dalszej kolejności i mniejszym zakresie - za "czerpiące” z transformacji spółdzielni).

Poza wymienionymi wyżej transformacjami w znaczeniu ścisłym należy dostrzegać w przepisach prawa także inne sposoby modyfikacji podmiotowych podmiotów prawa nie będące transformacjami sensu stricto, ale zbliżonymi do nich "transformacjami”, które można określać jako "quasitransformacje", takie jak np. wniesienie przedsiębiorstwa przedsiębiorcy jednoosobowego do spółki handlowej, w tym handlowej spółki osobowej czy spółki kapitałowej, w tym jednoosobowej spółki kapitałowej (spółki z ograniczoną odpowiedzialnością lub akcyjnej). Z uwagi na dosyć wyraźne uregulowanie ustawowe klasycznych rodzajów transformacji - łączenia, podziału i przekształcenia, w tym określenie zasad następstwa prawnego po podmiotach transformowanych ( $w$ formie ustrojowej właściwej - przed transformacją) albo ich kontynuacji prawnej (tj. odpowiednio sukcesji uniwersalnej albo kontynuacji), znaczenie przywołanych wyżej quasi-transformacji staje się coraz mniejsze [na temat różnic między zasadą sukcesji uniwersalnej i zasadą kontynuacji w kontekście procesów transformacyjnych wypowiada się m.in. Kidyba, MPH 2011, nr 1, 34 i n.; w literaturze dostrzega się również występowanie tzw. swoistego następstwa prawnego stanowiącego mix compositum między sukcesją uniwersalną i kontynuacją - zob. Kidyba, 2013, t. I, 183184; zob. również Sołtysiński, 2006, s. 375].

Możliwości transformacji w znaczeniu prawnym człowieka podlegają prawnej limitacji, która determinuje i odzwierciedla ich specyficzny charakter prawny.

Po pierwsze, prawne transformacje człowieka dotyczą w zasadzie jedynie obszaru prawa handlowego. Odnoszą się one do transformacji przedsiębiorców albo „w przedsiębiorców” - którzy prowadzą działalność gospodarczą. Do najważniejszych definicji przedsiębiorcy na gruncie prawa polskiego należy zaliczyć aktualnie pojęcie przedsiębiorcy unormowane $\mathrm{w}$ art. 43(1) kodeksu cywilnego - ustawy z dnia 23 kwietnia 1964 r. - Kodeks cywilny [tekst jedn.: Dz. U. z 2017 r., poz. 459 ze zm., dalej: k.c.], które ma znaczenie przede wszystkim na gruncie prawa prywatnego (w tym cywilnego), a także pojęcie przedsiębiorcy uregulowane w art. 4 ustawy z dnia 26 marca 2018 r. - Prawo przedsiębiorców [Dz. U. z 2018 r., poz. 646, dalej: p.p.], od- 
noszące się zwłaszcza do obszaru prawa publicznego (w tym administracyjnego). Kategoria działalności gospodarczej została z kolei zdefiniowana w art. 3, 5 i 6 p.p. (zob. w tym zakresie uwagi poniższe w pkt 3 tego opracowania).

Po drugie, transformacje te odnoszą się, co do zasady, do instytucji prawnych, które zostały przewidziane w prawie spółek, tj. zwłaszcza w kodeksie spółek handlowych.

Po trzecie, transformacje w znaczeniu prawnym człowieka dotyczą zasadniczo wyłącznie jednego z wyżej wymienionych rodzajów procesów transformacyjnych, tj. przekształcenia.

Po czwarte, transformacje te odnoszą się do tzw. szczególnych przypadków przekształcenia (tj. przekształcenia człowieka - osoby fizycznej, prowadzącej działalność gospodarczą - tzw. przedsiębiorcy jednoosobowego w jednoosobową spółkę kapitałową - z ograniczoną odpowiedzialnością albo akcyjną [zob. np. Kidyba, MPH 2011, nr 1, 38-40], a także przekształcenia ludzi - osób fizycznych będących wspólnikami spółki cywilnej w spółkę handlową [szerzej: Katner, PPH 2002, nr 11, 11-15; Sołtysiński, 2006, s. 374-379; Nita-Jagielski, Pr. Sp. 2006, nr 3, 9; Herbet, Szajkowski (red.), Kozieł, Frąckowiak (red.), 2013, 482-485].

Po piąte, co wynika po części z okoliczności wskazanej powyżej jako pierwsza, prawne transformacje człowieka (ludzi) łączą się z prowadzeniem określonej działalności (niekoniecznie gospodarczej) jedynie w ściśle normatywnie wskazanej „konfiguracji” podmiotowej. Konfiguracja ta pozostaje jako warunek konieczny - w powiązaniu z dokonywaną transformacją i ma związek z prowadzeniem działalności samodzielnie (co dotyczy prowadzenia działalności gospodarczej i przekształcenia w jednoosobową spółkę kapitałową) albo z innymi osobami (co z kolei odnosi się do prowadzenia działalności, niekoniecznie gospodarczej, w formie prawnej spółki cywilnej i przekształcenia w spółkę jawną albo inną spółkę handlową).

Po szóste, transformacje te opierają się na tzw. zasadzie swoistego następstwa prawnego [zob. np. Kidyba, MPH 2011, nr 1, 40], posiadającego cechy sukcesji uniwersalnej i kontynuacji po człowieku - osobie fizycznej prowadzącej działalność gospodarczą, tj. będącej tzw. przedsiębiorcą jednoosobowym (w przypadku przekształcenia w jednoosobową spółkę kapitałową) albo po ludziach - osobach fizycznych będących wspólnikami spółki cy- 
wilnej (w przypadku przekształcenia wspólników spółki cywilnej w spółkę handlową).

Należy wyrazić ogólną satysfakcję, że właśnie w prawie handlowym [Kozieł, Stec (red.), Załucki M. (red.), 81-93], a ściślej w jego bardzo istotnej części podmiotowej, tj. w prawie spółek możemy odnaleźć unormowania dotyczące transformacji człowieka w jednostkę organizacyjną (pozostające w określonym związku z prowadzeniem przez niego działalności gospodarczej). Oznacza to, że człowiek, jako podmiot prawa handlowego pozostaje w obszarze zainteresowania tej gałęzi (dziedziny) prawa, nie tylko z perspektywy jego szczególnej ochrony prawnej jako konsumenta (w ramach tzw. prawa konsumenckiego, które może być traktowane jako część prawa handlowego). Z drugiej jednak strony należy zauważyć, że jest to zainteresowanie, w zasadzie - poza unormowaniami dotyczącymi ochrony konsumentów - jedynie w kontekście procesów transformacyjnych i w znacznej mierze w perspektywie prowadzenia przez człowieka działalności gospodarczej.

\section{Przesłanki transformacji człowieka - osoby fizycznej prowadzącej działalność gospodarczą - tzw. przedsiębiorcy jednoosobowego w jednoosobową spółkę kapitałową}

Człowiek będący tzw. przedsiębiorcą jednoosobowym może przekształcić się w jednoosobową spółkę kapitałową (jednoosobową spółkę z ograniczoną odpowiedzialnością lub jednoosobową spółkę akcyjną - art. 551 $\S 5$ i art. 584(1)-584(13) k.s.h. [zob. np. Kidyba, MPH 2011, nr 1, 38-40]).

Do przesłanek prawnych tej transformacji człowieka (tj. tych, które warunkują jej dopuszczalność) należy zaliczyć przede wszystkim:

1) posiadanie przez człowieka statusu przedsiębiorcy w rozumieniu powszechnie obowiązujących przepisów prawa (tj. aktualnie w rozumieniu przepisów kodeksu cywilnego i ustawy - Prawo przedsiębiorców);

2) ograniczenie transformacji jedynie do przekształcenia (art. 584(1)584(13) k.s.h.);

3) ograniczenie przekształcenia jako sposobu transformacji wyłącznie do dwóch form prawnych wymienionych w katalogu transformacji spółek kapitałowych, stanowiących szczególne pod względem pod- 
miotowym ich przykłady, tj. do jednoosobowej spółki z ograniczoną odpowiedzialnością oraz do jednoosobowej spółki akcyjnej;

4) przeprowadzenie sformalizowanego postępowania dotyczącego przekształcenia, opartego na postępowaniu przekształceniowym spółek handlowych (przewidzianym w art. 556-582 k.s.h), jednak uregulowanego odrębnie w przepisach kodeksu spółek handlowych (tj. w art. 584(5)-584(12) k.s.h.).

Ad. 1. Nie wchodząc w szczegółową analizę zagadnienia definicji przedsiębiorcy, która wykracza poza cel i spektrum tego opracowania, należy dla porządku jedynie zasygnalizować, że przedsiębiorcą w rozumieniu przepisów kodeksu cywilnego i ustawy - Prawo przedsiębiorców jest osoba fizyczna, osoba prawna i jednostką organizacyjna niebędąca osobą prawną, której ustawa przyznaje zdolność prawną (art. 43(1) k.c. w zw. z art. 33(1) k.c.), która zgodnie z art. 43(1) k.c. „we własnym imieniu prowadzi”, natomiast w świetle art. 4 ust. 1 p.p. „wykonuje”, stosownie do art. 43(1) k.c. - "działalność gospodarczą lub zawodową", zaś zgodnie z art. 4 ust. 1 p.p. - działalność gospodarczą. Wydaje się, że poza różnicą w sformułowaniach między definicją zawartą w kodeksie cywilnym a definicją wprowadzoną przez Prawo przedsiębiorców nie ma istotnej dystynkcji merytorycznej. Najważniejsze różnice sprowadzają się do tego, że w art. 43(1) k.c. ustawodawca posługuje się sformułowaniem „prowadząca we własnym imieniu działalność gospodarczą lub zawodową”, natomiast w art. 4 ust. 1 p.p. „wykonująca działalność gospodarczą", przy czym działalność ta została zdefiniowana w art. 3 p.p., jako „zorganizowana działalność zarobkowa wykonywana we własnym imieniu". Można zatem przyjąć, że z wykładni językowej przepisów art. 3 i art. 4 p.p. wynika, iż tak jak to jest uregulowane $w$ art. 43(1) k.c., także w rozumieniu art. $4 \mathrm{w} z \mathrm{z} . \mathrm{z}$ art. 3 p.p. działalność gospodarcza powinna być wykonywana we własnym imieniu, a kategoria ta obejmuje także działalność zawodową (o ile jest zorganizowaną działalnością zarobkową wykonywaną we własnym imieniu). W art. 4 ust. 2 p.p. (podobnie jak w poprzedzającej wejście w życie ustawy - Prawo przedsiębiorców ustawie o swobodzie działalności gospodarczej) wyraźnie przewidziano, że przedsiębiorcą są także wspólnicy spółki cywilnej w zakresie wykonywanej przez nich działalności gospodarczej, co wyłącza z katalogu przedsiębiorców spółkę cywilną (wspól- 
ników spółki cywilnej). Regulacji prawnej przewidującej taką zasadę (dotyczącą odrębnie wspólników spółki cywilnej) ustawodawca tradycyjnie nie umieszcza w kodeksie cywilnym, w tym np. w art. 43(1) k.c., mając na uwadze to, że przepisy kodeksu cywilnego (ani jakiegokolwiek innego aktu prawnego) nie przyznają spółce cywilnej (wspólnikom spółki cywilnej) zdolności prawnej i zdolności do czynności prawnych, odmiennie niż np. kodeks spółek handlowych w stosunku do handlowych spółek osobowych.

Ad. 2. Przekształcenie jako forma transformacji podmiotowej polega na zmianie formy organizacyjno-prawnej podmiotu prawa podlegającego przekształceniu, w tym przedsiębiorcy jednoosobowego, zasadniczo przy zachowaniu jego tożsamości podmiotowej (przed i po przekształceniu) [Witosz, 2001, 8; Szumański, MPH 2011, nr 1, 9 i n.; Kozieł, Kidyba A. (red.), 2016, 1952]. Rozumiane w taki sposób przekształcenie odnosi się jedynie do spółek handlowych. W związku z tym, co do zasady, w przypadku przekształcenia podstawą prawną następstwa prawnego po podmiocie przekształcanym jest tzw. zasada kontynuacji, która polega na tym, że z dniem przekształcenia podmiot przekształcony (który jest prawnym „efektem” przekształcenia) staje się podmiotem praw i obowiązków podmiotu przekształcanego (a nie wstępuje w jego prawa i obowiązki, jak w przypadku sukcesji uniwersalnej) [zob. szerzej Kidyba, MPH 2011, nr 1, 34 i n.; Kozieł, Herbet (red.), Zakrzewski (red.), 2014, 54-64]. Przekształcenia człowieka - osoby fizycznej w jednoosobową spółkę kapitałową nie można jednak traktować jako przekształcenia w ścisłym tego słowa znaczeniu, przede wszystkim dlatego, że przekształceniu podlega działalność gospodarcza tzw. przedsiębiorcy jednoosobowego w jednoosobową spółkę kapitałową, stanowiącą odrębny od jedynego uczestnika tej spółki podmiot prawa. Związane z tradycyjnie pojmowanym przekształceniem założenie o tożsamości podmiotowej podmiotu przekształcanego i przekształconego jest w analizowanej sytuacji trudne, a w zasadzie niemożliwe do przyjęcia. Nie istnieje bowiem tożsamość podmiotowa między osobą fizyczną, która staje się jednoosobową spółką kapitałową (z udziałem tej osoby) i tą spółką, zarówno w znaczeniu faktycznym jak i, zasadniczo prawnym. Podobnie nie jest możliwe przyjmowanie zasady kontynuacji w ścisłym znaczeniu jako podstawy przysługiwania praw i obowiązków po przekształceniu. Z uwagi na unormowanie zawarte w ko- 
deksie spółek handlowych, z jednej strony i znaczne różnice w statusie prawnym podmiotu przekształcanego oraz przekształconego $w$ literaturze proponuje się, jak wyżej sygnalizowano, określanie tej zasady następstwa prawnego (przysługiwania) praw i obowiązków po przekształceniu jako swoistego następstwa prawnego) [Kidyba, MPH 2011, nr 1, 38-40], łączącego cechy sukcesji uniwersalnej i kontynuacji (do czego odnoszą się szerzej uwagi poniższe).

Ad. 3. Nie dokonując w tym miejscu, ze względu na cel i zakres tego opracowania, szczegółowej analizy teoretyczno-prawnej konstrukcji, charakteru prawnego, a także sposobu działania jednoosobowej spółki kapitałowej, szczegółowo przedstawionej w literaturze przedmiotu, należy stwierdzić, że spółką tą jest spółka kapitałowa z udziałem tylko jednego uczestnika (jednego wspólnika - w przypadku jednoosobowej spółki z ograniczoną odpowiedzialnością albo jednego akcjonariusza - w przypadku jednoosobowej spółki akcyjnej) [Michalski, Kidyba (red.), 2016, 1455-1460]. Należy przy tym zauważyć, że nie ma możliwości stosowania odnoszących się do przekształcenia tzw. przedsiębiorcy jednoosobowego w jednoosobową spółkę kapitałową unormowań (zgodnie z zasadami stosowania tych przepisów wynikającymi z powszechnie obowiązujących przepisów rozporządzenia w sprawie statutu SE [Rozporządzenie Rady (WE) nr 2157/2001 z dnia 8 października 2001 r.,Dz. U. UE.L 294 z dnia 10 listopada 2001 r., dalej: rozp. 2157/2001]oraz ustawy o Europejskim Zgrupowaniu Interesów Gospodarczych i Spółce Europejskiej [Ustawa z dnia 4 marca 2005 r., tekst jedn.: Dz. U. z 2015 r., poz. 2142 ze zm., dalej: ustawa o EZIG i SE] do spółki europejskiej (SE) z siedzibą na terytorium Rzeczypospolitej Polskiej, z uwagi na to, że jednym z podstawowych elementów tej spółki jest tworzenie przez co najmniej dwa podmioty pochodzące $z$ dwóch różnych państw członkowskich UE. Istotą jednoosobowej spółki kapitałowej (z ograniczoną odpowiedzialnością albo akcyjnej) jest natomiast tworzenie przez nie więcej niż jednego uczestnika (wspólnika albo akcjonariusza).

Ad. 4. Sformalizowane postępowanie przekształceniowe składa się z trzech faz (etapów):

a) fazy czynności przygotowawczych (przygotowawczej);

b) fazy czynności właścicielskich (właścicielskiej) i 
c) fazy rejestracji i ogłoszenia (rejestracyjnej),

na które składa się szereg szczegółowych czynności przewidzianych w art. 584(5)-584(12) k.s.h.) [szerzej zob. Kidyba, 2013, t. II, 1470-1487].

\section{Przesłanki transformacji ludzi - osób fizycznych będących wspólnikami spółki}

\section{cywilnej w spółkę handlową}

Ludzie będący wspólnikami spółki cywilnej mogą przekształcić się w spółkę handlową (jawną, partnerską, komandytową, komandytowo-akcyjną, z o.o. i akcyjną - art. 26 § 4-5 i art. 551 § 2-3 k.s.h.), a także, jak można sądzić, w EZIG i SE (art. 7 ustawy o EZIG i SE; art. 9 ust. 1, lit. c, pkt ii rozp. 2157/2001). Dotyczy to również sytuacji, w której wspólnikami spółki cywilnej są nie tylko osoby fizyczne, ale, poza osobami fizycznymi, także osoby prawne $\mathrm{i}$ jednostki organizacyjne niebędące osobami prawnymi, którym ustawa przyznaje zdolność prawną (art. 1 k.c. oraz art. 33(1) k.c. w zw. art. 860-875 k.c.). Dla dopuszczalności transformacji nie ma znaczenia, czy którykolwiek ze wspólników, w tym wspólnik będący osobami fizycznymi, prowadzi we własnym imieniu działalność gospodarczą, tzn. czy jest przedsiębiorcą.

Do przesłanek prawnych tej transformacji (tj. tych, które warunkują jej dopuszczalność z perspektywy prawnej) należy zaliczyć przede wszystkim:

1) posiadanie przez człowieka statusu wspólnika spółki cywilnej w rozumieniu przepisów kodeksu cywilnego (art. 860-875 k.c.);

2) ograniczenie transformacji do przekształcenia (art. $26 \S 4-5$ k.s.h., art. $551 \S 2-3$ k.s.h.);

3) ograniczenie przekształcenia do sześciu form prawnych wymienionych w katalogu przewidzianym w kodeksie spółek handlowych (tj. spółki jawnej, partnerskiej, komandytowej, komandytowo-akcyjnej, z ograniczoną odpowiedzialnością i akcyjnej), a także EZIG i SE;

4) przeprowadzenie postępowania dotyczącego przekształcenia uregulowanego przepisach kodeksu spółek handlowych w sposób odmienny w przypadku przekształcenia na podstawie art. 26 § 4-6 k.s.h. (tzw. przerejestrowania) i przekształcenia na podstawie art. 551 § 2-3 k.s.h. (przekształcenia w znaczeniu ścisłym) [zob. Sołtysiń- 
ski, 2006, s. 374-379; Nita-Jagielski, Pr. Sp. 2006, nr 3, 9; Herbet, Szajkowski (red.), Kozieł, Frąckowiak (red.), 2013, 482-485].

Ad. 1. Wspólnikiem spółki cywilnej może być każdy podmiot prawa, a zatem także osoba fizyczna [zob. Kidyba, Kopaczyńska-Pieczniak, Kidyba (red.), 2014, 1229-1232]. Status wspólnika spółki cywilnej wiąże się z zawarciem przez osobę fizyczną umowy tej spółki w formie pisemnej (dla celów dowodowych), w której zostaną wskazane co najmniej wspólny cel gospodarczy wspólników tej spółki (do którego realizacji wspólnicy zobowiązują się dążyć), a także sposób współdziałania wspólników dla realizacji tego wspólnego celu, tj. np. działanie w sposób oznaczony w umowie spółki lub wniesienie do spółki wkładów. Wspólnik spółki cywilnej nie musi być przedsiębiorcą. Poprzez zawarcie umowy spółki cywilnej jej wspólnik nie staje się przedsiębiorcą, nawet w przypadku, gdyby pozostali wspólnicy prowadzili działalność gospodarczą i posiadali status prawny przedsiębiorcy.

Ad. 2. Przekształcenie stanowi jedną z form transformacji podmiotowej. Polega na zmianie formy organizacyjno-prawnej podmiotu prawa podlegającego przekształceniu, w tym np. wspólników spółki cywilnej, co do zasady z zachowaniem jego tożsamości podmiotowej (przed i po przekształceniu) [Witosz, 2001, 8; Szumański, MPH 2011, nr 1, 9 i n.; Kozieł, Kidyba A. (red.), 2016, 1952]. Takie znaczenie określenia „przekształcenie” dotyczy w zasadzie jedynie spółek handlowych. W przypadku typowego przypadku przekształcenia podstawą prawną następstwa prawnego po podmiocie przekształcanym jest tzw. zasada kontynuacji, która polega na tym, że z dniem przekształcenia podmiot przekształcony (który jest prawnym „efektem” przekształcenia) staje się podmiotem praw i obowiązków podmiotu przekształcanego (zob. także uwagi zawarte w pkt. 3 powyżej).Przekształcenia wspólników spółki cywilnej będących osobami fizycznymi w spółkę handlową nie można traktować jako przekształcenia w ścisłym tego słowa znaczeniu. W tym przypadku przekształceniu podlega bowiem stosunek prawny spółki cywilnej (a nie podmiot prawa), w którym uczestniczą jako wspólnicy osoby fizyczne, w spółkę handlową, stanowiącą odrębny od jej wspólników podmiot prawa. Łączone ze standardowo rozumianym przekształceniem założenie o tożsamości podmiotowej podmiotu przekształcanego i przekształconego w analizowanej sytuacji może być bardzo trudne, a w zasadzie niemożliwe 
do przyjęcia. Nie ma bowiem tożsamości podmiotowej między osobą fizyczną (czy osobami fizycznymi), która staje się (stają się) spółką handlową (z udziałem tej osoby, tych osób jako uczestnika, uczestników) i tą spółką, zarówno w znaczeniu faktycznym i, co do zasady, prawnym. W związku z tym, nie jest możliwe przyjmowanie zasady kontynuacji w ścisłym znaczeniu jako podstawy przysługiwania praw i obowiązków po przekształceniu. Ze względu na regulacje kodeksu spółek handlowych z jednej strony i znaczne dystynkcje w statusie prawnym podmiotu przekształcanego oraz przekształconego w literaturze proponuje się, jak wyżej sygnalizowano, określanie tej zasady następstwa prawnego (przysługiwania) praw i obowiązków po przekształceniu jako tzw. zasady swoistego następstwa prawnego [zob. Kidyba, 2013, t. I, 183-184] łączącego cechy sukcesji uniwersalnej i kontynuacji (do czego odnoszą się uwagi poniższe w pkt 5).

Ad. 3. W związku z wyraźnym unormowaniem art. 26 § 4-6 k.s.h. i art. 551 § 2-3 k.s.h. zagadnienie dopuszczalności przekształcenia spółki cywilnej (w zasadzie wspólników spółki cywilnej) w którąkolwiek z katalogu sześciu spółek handlowych uregulowanych w kodeksie spółek handlowych w zasadzie nie budzi wątpliwości. W tym obszarze należy ostrożnie rozważyć możliwość stosowania unormowań odnoszących się do tego rodzaju przekształceń (wymienionych wyżej) odpowiednio do Europejskiego Zgrupowania Interesów Gospodarczych (EZIG, z siedzibą na terytorium RP). Są to unormowania odnoszące się do spółki jawnej, natomiast zgodnie z przepisami dotyczącymi EZIG z siedzibą na terytorium RP (w tym zwłaszcza art. 7 ustawy o EZIG i SE), do tej jednostki organizacyjnej w zakresie nieuregulowanym w rozporządzeniu w sprawie EZIG oraz ustawie o EZIG i SE stosuje się odpowiednio przepisy dotyczące spółki jawnej, a zatem, jak można sądzić, także przepisy o przekształceniu w spółkę jawną (art. 26 § 4-6 k.s.h.), jak również przepisy o przekształceniu spółki jawnej w inną spółkę handlową (art. $551 \S 1$ k.s.h.). W związku z tym wypada opowiedzieć się raczej za dopuszczalnością takiej transformacji (wspólników spółki cywilnej w EZIG) niż przeciwko niej. Dotyczy to oczywiście jedynie przypadku wspólników spółki cywilnej posiadających miejsce zamieszkania lub siedzibę w różnych państwach członkowskich UE, a zatem sytuacji, w której w spółce cywilnej występuje tzw. element transgraniczny, wymagany w EZIG (czy SE). Trzeba mieć przy tym na uwadze, że w 
przypadku EZIG przepisy prawa przewidują wyraźnie jedynie jeden sposób powstania, tj. zawarcie umowy i wpis do rejestru (KRS). Przyjęcie możliwości powstania EZIG w drodze przekształcenia wspólników spółki cywilnej, w której występuje tzw. element transgraniczny stanowi zatem, w tym kontekście stosunkowo nowatorskie spojrzenie interpretacyjne na odnoszące się do EZIG z siedzibą na terytorium RP regulacje prawne, uwzględniające nie tylko rezultaty wykładni językowej (gramatycznej), ale także argumenty wynikające z wykładni systemowej i funkcjonalnej.

Podobne argumenty przemawiają za dopuszczeniem możliwości przekształcenia wspólników spółki cywilnej w SE z siedzibą na terytorium RP. Przepisy prawa dotyczące SE z siedzibą na terytorium RP nie przewidują wyraźnie możliwości powstania SE w drodze przekształcenia spółki cywilnej (wspólników spółki cywilnej). Unormowania art. 551 \& 2 k.s.h. odnoszą się do spółki akcyjnej (tj. m. in. możliwości jej powstania w rezultacie przekształcenia spółki cywilnej - wspólników spółki cywilnej). Zgodnie z przepisami dotyczącymi SE z siedzibą na terytorium RP (w tym przede wszystkim przepisem art. 9 ust. 1, lit. c, pkt ii rozp. 2157/2001), do tej jednostki organizacyjnej w sprawach nieuregulowanych w rozporządzeniu w sprawie statutu SE (oraz ustawie o EZIG i SE zawierającej przepisy przyjęte w celu wprowadzenia w życie tego rozporządzenia $w$ znaczeniu art. 9 ust. 1, lit. c, pkt. i rozp. 2157/2001) lub w przypadku gdy są one uregulowane w nim jedynie częściowo, w zakresie pozostawionym poza niniejszym rozporządzeniem, stosuje się przepisy dotyczące spółki akcyjnej, a zatem, jak można sądzić, także przepisy o przekształceniu wspólników spółki cywilnej w spółkę akcyjną (art. 551 § 2 k.s.h.). Dopuszczalność takiej transformacji (wspólników spółki cywilnej w SE) odnosi się oczywiście jedynie przypadku wspólników spółki cywilnej posiadających miejsce zamieszkania lub siedzibę w różnych państwach członkowskich UE, a zatem sytuacji, w której w spółce cywilnej występuje tzw. element transgraniczny, wymagany w SE (czy EZIG). Podobnie jak w przypadku EZIG, przyjęcie możliwości powstania SE w drodze przekształcenia ze wspólników spółki cywilnej, w której występuje tzw. element transgraniczny stanowi wyraz dosyć nowatorskiego spojrzenia interpretacyjnego na odnoszące się do SE z siedzibą na terytorium RP regulacje prawne, które 
uwzględnia nie tylko wykładnię językową (gramatyczną), ale także systemową i funkcjonalną.

Ad. 4. Nie wchodząc w szczegółową analizę zagadnienia postępowania przekształceniowego spółki cywilnej (wspólników spółki cywilnej), co nie jest celem tego opracowania, należy stwierdzić, że postępowanie to, w przypadku przekształcenia na podstawie art. $26 \S 4-5$ k.s.h. (tzw. przerejestrowania) w spółkę jawną polega w zasadzie jedynie na zmianie (w tym dostosowaniu) umowy spółki cywilnej do wymogów przewidzianych dla umowy spółki jawnej i zgłoszeniu jej do Krajowego Rejestru Sądowego [Ustawa z dnia 20 sierpnia 1997 r., tekst jedn. Dz. U. z 2017 r., poz. 700]. Ma zatem charakter uproszczony $w$ porównaniu do pozostałych postępowań przekształceniowych uregulowanych $w$ kodeksie spółek handlowych. Przekształcenie na podstawie art. 551 \& 2-3 k.s.h. (przekształcenie w znaczeniu ścisłym) łączy się z kolei z obowiązkiem przeprowadzenia sformalizowanej procedury przekształceniowej składającej się z trzech faz określanych jako faza przygotowawcza (menadżerska), faza właścicielska i sądowa (rejestracyjna) [zob. Kidyba, 2013, t. II, 1360, 1380 i n.], przy czym każda z tych faz składa się z wielu zróżnicowanych czynności.

Przypadek, w którym poza ludźmi (osobami fizycznymi), wspólnikami spółki cywilnej są także osoby prawne czy jednostki organizacyjne niebędące osobami prawnymi, którym ustawa przyznaje zdolność prawną nie wpływa na zakres wymienionych wyżej przesłanek prawnej dopuszczalności przekształcenia tej spółki w spółkę handlową, EZIG i SE (czy jej charakter prawny). Wskazany sposób ukształtowania stosunku prawnego spółki cywilnej ma natomiast znaczenie z perspektywy skutków prawnych tej transformacji, czego dotyczy w niniejszym opracowaniu pkt. 5 poniżej.

\section{Skutki prawne transformacji człowieka w jednostkę organizacyjną}

Podstawowym skutkiem transformacji człowieka (osoby fizycznej) w jednostkę organizacyjną (wspólnym dla każdego z prezentowanych wyżej w pkt. 3 i 4 dwóch jej wariantów) jest szczególne (specyficzne) następstwo prawne jednoosobowej spółki kapitałowej (albo, w drugim przypadku spółki handlowej, EZIG czy SE), po człowieku będącym, w pierwszym przypadku tzw. przedsiębiorcą jednoosobowym albo - w drugim przypadku - po wspól- 
nikach spółki cywilnej (w tym przynajmniej jednym z nich, będącym osobą fizyczną) wynikające w pierwszym z analizowanych przypadków przekształcenia z przepisu art. 584(2) k.s.h., natomiast $w$ drugim - z przepisu art. $551 \S$ 3 k.s.h. Określa się je w literaturze przedmiotu jako następstwo prawne posiadające cechy sukcesji uniwersalnej i kontynuacji, nie stanowiące jednocześnie ani sukcesji uniwersalnej ani kontynuacji (swoiste następstwo prawne). Następstwo to polega generalnie na tym, że przekształcony (podmiot w formie docelowej) staje się z dniem przekształcenia podmiotem praw i obowiązków przysługujących przekształconemu (podmiotowi bądź grupie podmiotów w formie początkowej, przed przekształceniem, tj. tzw. przedsiębiorcy jednoosobowemu albo wspólnikom spółki cywilnej, w tym osobom fizycznym lub osobom fizycznym oraz osobom prawnym czy jednostkom organizacyjnym niebędącym osobami prawnymi, które posiadają zdolność prawną). Zarówno znaczenie zasady następstwa, jak i jego zakres (zwłaszcza podmiotowy) może zatem, tak z perspektywy abstrakcyjnej, jak i konkretnej, budzić określone wątpliwości, natury ogólnej oraz szczegółowej, co znalazło swoje odzwierciedlenie w wypowiedziach zawartych w literaturze przedmiotu [zob. w tym zakresie w szczególności wypowiedzi Kidyby, MPH 2011, nr 1, 38 i n.; 2013, t. I, 183-184; Sołtysińskiego, 2006, s. 374-379; Nita-Jagielskiego, Pr. Sp. 2006, nr 3, 9; Herbeta, Szajkowski (red.), Kozieła, Frąckowiak (red.), 2013, 482-485].

Do pozostałych skutków tej transformacji należy zaliczyć przede wszystkim:

1) skutki w zakresie odpowiedzialności za zobowiązania powstałe przed przekształceniem (art. 584(13) k.s.h. i art. 583-584 k.s.h.);

2) skutki w zakresie odpowiedzialności osób działających i biegłego rewidenta (art. 584(10) k.s.h. i art. 568 k.s.h.);

3) skutki w obszarze zmiany oznaczenia (firmy lub nazwy) przekształcanego, która nie polega tylko na modyfikacji dodatku obligatoryjnego wskazującego na jego formę prawną (art. 584(3) k.s.h. i art. 554 k.s.h.),

4) skutki w obszarze roszczeń podmiotów nie uczestniczących w przekształceniu (w przypadku przekształcenia wspólników spółki cywilnej), w tym roszczeń związanych z wyceną ich „praw udziałowych" (art. 565-566 k.s.h.). 
W przypadku, w którym poza osobami fizycznymi, wspólnikami spółki cywilnej są także osoby prawne czy jednostki organizacyjne niebędące osobami prawnymi, którym ustawa przyznaje zdolność prawną skutki prawne przekształcenia (w spółkę handlową, EZIG czy SE) przypadają jednostkom organizacyjnym stanowiącym prawny rezultat przekształcenia. Dotyczą one niejako "łącznie” nie tylko osób fizycznych, ale także jednostek organizacyjnych (w tym osób prawnych i jednostek organizacyjnych niebędących osobami prawnymi, którym ustawa przyznaje zdolność prawną), które były wspólnikami spółki cywilnej jedynie w zakresie, w jakim konsekwencje prawne przekształcenia mogą odnosić się do uczestników jednostek organizacyjnych, stanowiących podmioty przekształcone (w finalnej formie przekształcenia), np. w obszarze kontynuacji praw i obowiązków członkowskich (wynikających ze stosunku uczestnictwa), odpowiedzialności za zobowiązania powstałe przed przekształceniem, odpowiedzialności osób działających czy zmiany oznaczenia (firmy lub nazwy) przekształcanego, która nie polega tylko na modyfikacji dodatku obligatoryjnego wskazującego na jego formę prawną.

\section{Podsumowanie}

W podsumowaniu niniejszego opracowania można sformułować kilka wniosków o charakterze zarówno ogólnym, jak i szczegółowym.

Po pierwsze, możliwości transformacji człowieka (w obszarze regulacji prawa handlowego) $\mathrm{w}$ jednostkę organizacyjną w prawie handlowym są ograniczone:

1) w przypadku tzw. przedsiębiorcy jednoosobowego w jednoosobową spółkę kapitałową - do przekształcenia w którąkolwiek z dwóch form jednoosobowych spółek kapitałowych (jednoosobową spółkę z ograniczoną odpowiedzialnością lub jednoosobową spółkę akcyjną);

2) w przypadku wspólników spółki cywilnej - do przekształcenia w jakąkolwiek formę spółki handlowej, a także w EZIG i SE.

Po drugie, jedyną dopuszczalną formą transformacji jest przekształcenie, w tym jego szczególne przypadki (tj. przekształcenie człowieka w jedno- 
osobowa spółkę kapitałową, a także przekształcenie człowieka będącego wspólnikiem spółki cywilnej w spółkę handlową, EZIG i SE).

Po trzecie, z przekształceniem wspólników spółki cywilnej w EZIG czy SE jest obowiązkowo związany tzw. element transgraniczny, co oznacza, że przynajmniej dwóch wspólników spółki cywilnej powinno mieć miejsca zamieszkania lub siedziby w dwóch różnych Państwach Członkowskich UE.

Po czwarte, w każdym z dopuszczanych przypadków transformacji (przekształcenia) obowiązuje jako zasada następstwa prawnego (przysługiwania praw) po przekształcanym tzw. zasada swoistego następstwa prawnego posiadająca cechy sukcesji uniwersalnej i kontynuacji.

\section{Bibliografia}

Longchamps de Berier R., Wstęp do nauki prawa cywilnego, Lublin 1922.

Frąckowiak J., Jednostka organizacyjna jako substrat osoby prawnej i ustawowej (w:) Rozprawy prawnicze. Księga pamiątkowa Profesora Maksymiliana Pazdana, Ogiegło L. (red.), Popiołek W. (red.), Szpunar M. (red.), Kraków 2005.

Frąckowiak J. [w:] System Prawa Prywatnego, t. 1, Safjan M. (red.), Warszawa 2007.

Herbet A. (w:) System prawa prywatnego, Radwański Z. (red.), t. 16, Prawo spółek osobowych, Szajkowski A. (red.), Warszawa 2008.

Katner W.J., Problemy funkcjonowania spółki cywilnej w nowej rzeczywistości prawnej, PPH 2002, nr 11.

Kidyba A., Kodeks spółek handlowych, t. I. Komentarz do art. 1-300, Warszawa 2013.

Kidyba A., Kodeks spółek handlowych, t. II. Komentarz do art. 1-300, Warszawa 2013.

Kidyba A., Sukcesja, kontynuacja, a może coś innego?, Monitor Prawa Handlowego 2011, nr 1.

Kidyba A., Kopaczyńska-Pieczniak K. (w:) Gawlik Z., Janiak A., Kidyba A., Kopaczyńska-Pieczniak K., Kozieł G., Niezbiecka E., Sokołowski T., Kodeks cywilny. Komentarz, t. III, Zobowiązania, cz. szczególna, Kidyba (red.), Warszawa 2014. 
Kozieł G., Procesy transformacyjne spółki (w:) Prawo spółek, Kidyba A. (red.), Warszawa 2016.

Kozieł G., Przekształcenie spółki cywilnej w spółki handlowe w nowelizacjach k.s.h. a przesłanki rozwiązania tej spółki. Zagadnienia wybrane (w:) Kodeks spółek handlowych po dziesięciu latach, Frąckowiak J. (red.), Wrocław 2013. Kozieł G., Uwagi podstawowe o umiejscowieniu regulacji prawa handlowego w kodeksie cywilnym i projekcie kodeksu cywilnego (w:) 50 lat kodeksu cywilnego. Perspektywy rekodyfikacji, Stec P. (red.), Załucki M. (red.), Warszawa 2015.

Kozieł G., Zasada kontynuacji w procesach transformacyjnych spółdzielni prawa polskiego. Kilka refleksji (w:) Podstawowe konstrukcje i tendencje rozwojowe prawa spółdzielczego, Herbet A. (red.) i Zakrzewski P. (red.), Lublin 2014.

Michalski M., Charakter prawny i zastosowanie spółki akcyjnej (w:) Prawo spółek, Kidyba A. (red.), Warszawa 2016.

Nita-Jagielski G., Następstwo prawne między wspólnikami spółki cywilnej a spółką handlową powstającą z przekształcenia spółki cywilnej, Pr. Sp. 2006, nr 3.

Radwański Z., Prawo cywilne - część ogólna, Warszawa 2003.

Rozporządzenie Rady (WE) nr 2157/2001 z dnia 8 października 2001 r. w sprawie statutu spółki europejskiej (SE),Dz.U. UE.L 294, z dnia 10 listopada 2001 r., s. 1-21.

Sokołowski T. (w:) Gawlik Z., Janiak A., Jedliński A., Kidyba A., KopaczynskaPieczniak K., Niezbecka E., Sokołowski T., Kodeks cywilny. Komentarz, t. I, Część ogólna, A. Kidyba (red.), Warszawa 2012.

Sołtysiński S. (w:) Sołtysiński S., Szajkowski A., Szumański A., Szwaja J., Kodeks spółek handlowych. Komentarz, t. 1, Warszawa 2006.

Szumański A., Nowe rodzaje przekształceń w spółki handlowe - uwagi systemowe, Monitor Prawa Handlowego 2011, nr 1.

Ustawa z dnia 4 marca 2005 r. o Europejskim Zgrupowaniu Interesów Gospodarczych i Spółce Europejskiej, tekst jedn.: Dz. U. z 2015 r., poz. 2142 ze $\mathrm{zm}$. 
Ustawa z dnia 23 kwietnia 1964 r. - Kodeks cywilny, tekst jedn.: Dz. U. z 2017 r., poz. 459 ze zm.

Ustawa z 15 września 2000 r. - Kodeks spółek handlowych, tekst jedn.: Dz.U. z 2017 r., poz. 1577 ze zm.

Ustawa z dnia 20 sierpnia 1997 r. o Krajowym Rejestrze Sądowym, tekst jedn. Dz. U. z 2017 r., poz. 700.

Ustawa z dnia 26 marca 2018 r. - Prawo przedsiębiorców, Dz. U. z 2018 r., poz. 646.

Ustawa z 16 września 1982 r. - Prawo spółdzielcze, tekst jedn.: Dz. U. z 2017 r., poz. 1560.

Witosz A., Przekształcenia spółek w kodeksie spółek handlowych, BydgoszczKatowice 2001.

Witosz A., Przekształcenie spółdzielni pracy w spółkę handlową (w:) Podstawowe konstrukcje i tendencje rozwojowe prawa spółdzielczego, Herbet A. (red.) i Zakrzewski P. (red.), Lublin 2014.

Wolter A., Prawo cywilne. Zarys części ogólnej, Warszawa 1986.

Zoll F., Prawo cywilne w zarysie, t. I, z. 1, Kraków 1946. 